\title{
ANALISIS CAPAIAN PERKEMBANGAN BAHASA ANAK USIA DINI DALAM KEGIATAN PEMBELAJARAN DENGAN METODE LEARNING BASED RESOURCES
}

\author{
Dadang Kurnia ${ }^{1}$ \\ Mohamad Taufiq² \\ Endah Silawati ${ }^{3}$
}

\begin{abstract}
ABSTRAK
Berdasarkan observasi awal bahwa rata-rata 3 s.d $10 \%$ anak usia sekolah mengalami masalah kemampuan bahasa, dengan gejala kemampuan pemahaman kosa kata di bawah rata-rata; kesalahan penggunaan struktur bahasa; bermasalah dalam membuat kalimat kompleks dan sulit mengingat kata. Dari fakta tersebut, penditeksian dini tentang bagaimana kemampuan bahasa anak perlu dilakukan, sehingga bisa diperbaiki sejak awal. Selain itu, perlu disusun model pembelajaran yang tepat. Resources based Learning merupakan salah satu model pembelajaran yang memaksimalkan penggunaan sumber-sumber belajar sebagai alat untuk membantu anak dalam belajar. Model ini sesuai dengan prinsip belajar anak usia dini yang masih bersifat konkrit. Penelitian dilakukan di TK Alif, Rancaekek, Kab. Bandung dengan subjek 7 orang anak yang dipilih secara random. Metode mix method diterapkan pada penelitian ini. Hasil penelitian menunjukan bahwa kemampuan bahasa anak setelah mengikuti kegiatan pengembangan bahasa dengan metode Learning based Resources mencapai nilai rata-rata 3,65 yang memiliki makna sudah konsisten. Sumber belajar yang digunakan dalam pengaplikasian metode ini adalah manusia, buku dan media audio visual. Diantara tiga sumber belajar tersebut, media audio visual dinilai paling efektif karena mendapat nilai ratarata paling tinggi diantara dua sumber belajar lainnya. Berdasarkan temuan tersebut, disarankan pada guru untuk memanfaatkan berbagai sumber belajar di sekitar anak.
\end{abstract}

Kata Kunci : kemampuan bahasa anak, metode learning based resources, pembelajaran anak usia dini.

\section{A. PENDAhUluAN}

Era komunikasi global saat ini mendudukan bahasa sebagai kemampuan yang sangat penting untuk dikuasai dengan baik karena segala sumber ilmu dan informasi bermediakan bahasa. Oleh sebab itu, kemampuan bahasa perlu dikembangkan sejak dini pada masa periode kritis (masa emas) perkembangan bahasa anak. Ketika kemampuan bahasa anak terhambat, maka dikhawatirkan akses anak terhadap ilmu dan informasi akan terhambat. Selain itu, lebih dari sebagai alat komunikasi, bahasa adalah cara menggungkapkan kreatifitas dan alat mengungkapkan fikiran, ide dan

\footnotetext{
${ }^{1}$ Dosen Universitas Terbuka

2 Dosen Universitas Terbuka

${ }^{3}$ Dosen Kampus UPI Cibiru
} 
emosi (Logan, 1972). Dengan kata lain, bahasa adalah tangan dari pikiran. Maksudnya, setiap hasil pemikiran diungkapkan lewat bahasa sehingga hasil pemikiran tersebut menjadi bermakna, berkembang dan digunakan untuk memecahkan masalah.

Sayangnya, mayoritas pembelajaran bahasa di TK masih menggunakan cara konvensional, bersifat akademis dan jauh dari suasana bermain. Pengembangan bahasa di TK selama ini lebih menekankan pada kemampuan teknis membaca dan menulis, bukan bagaimana cara mengekspresikan ide melalui bahasa. Selain itu, suasana pembelajaran masih cenderung otoriter dengan guru sebagai pusat kegiatan belajar dan tidak bersifat demokrastis. Strategi pengajaran belum sesuai dengan prinsip-prinsip pembelajaran bagi anak seperti belajar secara aktif dengan melibatkan anak dalam kegiatan melihat, mendengar, meraba dan memanipulasi.

Penggunaan metode pembelajaran bahasa yang tepat dan sesuai dengan karakteristik perkembangan anak usia dini merupakan kunci keefektifan pembelajaran. Salah satu metode yang diasumsikan efektif dan sesuai dengan perkembangan anak adalah metode Resources based Learning. Metode ini merupakan salah satu model pembelajaran yang memaksimalkan penggunaan sumber-sumber belajar sebagai alat untuk membantu anak dalam belajar. Metode ini sesuai dengan karakteristik anak usia dini yang masih bersifat konkrit (Suyanto, 2005).

Dalam konteks pendidikan anak usia dini, penggunaan metode ini belum banyak dikaji. Penelitian-penelitian sebelummnya lebih banyak diaplikasikan dalam pembelajaran di Sekolah Dasar (SD) dan jenjang yang lebih tinggi. Dalam konteks pembelajaran di tingkat tersebut, menunjukan bahwa metode ini cukup efektif dalam membantu pembelajaran siswa. Karena itu, merupakan sebuah tantangan untuk mengkaji metode ini dalam konteks pembelajar anak usia dini, khususnya dalam pengembangan kemampuan bahasa. Artikel ini akan menyajikan kajian mengenai analisis capaian perkembangan kemampuan bahasa anak yang telah mengikuti pembelajaran dengan metode Learning based Resources.

\section{B. PEMBAHASAN}

\section{Kajian Pustaka}

Pada dasarnya kemampuan bahasa dikelompokan dalam dua kelompok, yaitu kemampuan bahasa reseptif dan ekspresif (Bowen, 1998). Kemampuan bahasa reseptif melingkupi kemampuan membaca dan mendengar, sedangkan kemampuan bahasa ekspresif melingkupi berbicara dan menulis. Keempat kemampuan tersebut saling mempengaruhi satu sama lain. Sesuai dengan penelitian klasik Loban di tahun 1960 yang menemukan bahwa anak yang kemampuan dasar bahasanya tinggi, maka kemampuan membacanya pun tinggi dan anak yang kemampuan dasar bahasanya rendah, maka kemampuan membacanya pun rendah (Logan, 1972). Penelitian tersebut juga mengungkapkan bahwa kemampuan bahasa lisan berkaitan erat dengan kemampuan bahasa tulis. Anak yang kemampuan bahasa lisannya baik maka kemampuan bahasa tulisnya pun baik pula.

Proses kemampuan bahasa anak berproses melalui tahapan tertentu sesuai dengan usianya (Peterson, 1996). Logan (1972) membagi tahapan perkembangan bahasa mulai dari tahap randon, jargon, echalalia, ekspansi sampai dengan tahap 
kreatif. Dalam mengembangkan kemampuan berbahasa, anak memerlukan orang dewasa yang memberi stimulasi, baik di rumah, sekolah maupun lingkungan sekitarnya. Orang dewasa memerlukan waktu dalam membantu mengajarkan anak berbahasa, mulai dari tahap signal ke simbol, dari suara ke kata-kata dan dari katakata ke kemampuan komunikasi. Ketika anak menemukan sesuatu di dunia sekitar, anak memerlukan bantuan orang dewasa untuk memastikan apa yang dipelajarinya adalah benar.

Setiap tahapan perkembangan bahasa memerlukan stimulasi yang tepat dan situasi yang memungkinkan anak dapat mengembangkan kemampuan bahasanya. Mereka membutuhkan suatu kesempatan untuk bisa berbicara, berdiskusi, menyusun hipotesis dan sintesis. Pembelajaran bahasa pada anak usia dini harus berada pada situasi dimana memungkinkan anak memiliki kesempatan untuk mencelupkan diri, terlibat aktif, mendapatkan contoh nyata, mendapatkan kesempatan dan tanggung jawab, mempraktekan dan mengira-ira, serta memperoleh respon yang tepat dari orang dewasa (Cox, 1999 dalam Musfiroh, 2009). Karena itu, guru atau orang dewasa di sekitar anak sebagai fasilitator sebaiknya menyusun pembelajaran yang memberikan stimulasi perkembangan bahasa anak seperti diskusi, cerita yang kreatif, film, dsb. Hal tersebut akan membantu menciptakan makna dari pengalaman mereka sendiri dalam dunia nyata ke dalam variasi simbol linguistik yang lebih luas. Selain itu, hal yang harus diperhatikan dalam pengembangan bahasa anak adalah tahapan perkembangan anak secara keseluruhan, karena pada usia ini terjadi perkembangan pesat dalam berbagai aspek perkembangan anak yang akan sangat menentukan taraf optimalisasi perkembangan berikutnya (Yawkey dkk, 1981).

Salah satu metode pembelajaran yang diasumsikan efektif dalam pengembangan bahasa anak adalah Learning based Resources. Menurut Suryosubroto (2001) Learning based resources adalah suatu pendekatan yang dirancang untuk memudahkan anak dalam mengatasi keterampilan anak tantang luas dan keanekaragaman sumber-sumber informasi yang dapat dimanfaatkan untuk belajar. Adapun menurut Nasution (2006) Learning based resources adalah segala bentuk belajar yang langsung menghadapkan anak dengan sesuatu atau sejumlah individu atau kelompok dengan segala kegiatan belajar yang berkaitan dengan itu, bukan dengan cara konvensional dimana guru menyampaikan beban pelajaran kepada anak. Metode ini bertemali dengan metode inquiry dimana anak menemukan sendiri pengetahuan yang belum diketahuinya. belajar berdasarkan sumber berusaha memberi pengertian kepada anak tentang luas dan aneka ragamnya sumber-sumber informasi yang dapat dimanfaatkan untuk belajar. Sumber-sumber itu berupa sumber dari masyarakat dan lingkungan manusia, museum, organisasi, bahan cetakan, perpustakaan, alat audio-visual, dan sebagainya. Anak harus diajarkan teknik melakukan kerja lapangan, menggunakan perpustakaan, buku referensi, sehingga mereka lebih percaya diri.

Belajar berdasarkan sumber atau Learning based resources bukan sesuatu yang berdiri sendiri, melainkan bertalian dengan sejumlah perubahan-perubahan yang mempengaruhi pembinaan kurikulum. Perubahan-perubahan itu mengenai : (1) perubahan dalam sifat dan pola ilmu pengetahuan manusia, (2) perubahan dalam masyarakat dan taksiran kita tentang tuntutannya, (3) perubahan mengenai 
pengertian kita tentang anak dan cara-cara belajar, dan (4) perubahan dalam media komunikasi.

Karakteristik belajar berdasarkan sumber adalah dengan memanfaatkan sepenuhnya segala sumber informasi sebagai sumber bagi pelajaran termasuk alatalat audio-visual dan memberi kesempatan untuk merencanakan kegiatan belajar dengan mempertimbangkan sumber-sumber yang tersedia (Nasution, 2006). Ini tidak berarti bahwa pengajaran berbentuk kuliah atau ceramah ditiadakan akan tetapi dapat digunakan segala macam metode yang dianggap paling sesuai untuk tujuan tertentu. Model pembelajaran ini bertujuan untuk membuat anak belajar aktif yang didorong oleh minat dan keterlibatan diri dalam proses pembelajaran. Karena itu, apa yang dipelajari harus bermakna dan bervariasi.

Belajar berdasarkan sumber memberi kesempatan kepada anak untuk bekerja menurut kecepatan dan kemampuan setiap anak. Selain itu, metode ini lebih flexibel dalam penggunaan waktu dan ruang belajar. Hal tersebut akan mengembangkan kepercayaan diri anak dalam belajar dan menumbuhkan motivasi anak untuk belajar sepanjang hidupnya.

Dalam pelaksanaan model Learning based Resources, perlu diperhatikan halhal sebagai berikut (Nasution, 2006): (1) Pengetahuan dikembangkan berdasarkan pengetahuan guru tentang latar belakang anak dan pengetahuan anak tentang bahan pelajaran, (2) Guru harus merumuskan dengan jelas tujuan yang apa yang ingin dicapai dengan pelajaran itu, (3) Metode pengajaran banyak ditentukan oleh tujuan dan (4) adanya ketersediaan media yang diperlukan, khususnya yang dimilki oleh sekolah.

Adapun tahapan pelaksanaan model pembelajaran ini menurut Suryosubroto (2001) adalah sebagai berikut :

1. Menjelaskan tujuan mengumpulkan suatu informasi tertentu pada anak.

2. Merumuskan tujuan pembelajarannya (indikator).

3. Mengiidentifikasikan kemampuan informasi yang dimiliki anak.

4. Menyiapkan sumber-sumber belajar yang potensial dengan baik.

5. Menentukan cara bagaimana anak akan mendemonstrasikan hasil belajarnya.

6. Menentukan bagaimana informasi yang diperoleh oleh anak itu dikumpulkan,

7. Menentukan alat evaluasi untuk mengukur keberhasilan proses dan penyajian hasil belajar mereka.

Tahapan metode pembelajaran ini perlu mengalami penyesuaian dalam konteks pembelajaran anak usia dini. Misalnya penggunaan bahasa dalam menjelaskan tujuan pengumpulan informasi dan tujuan pembelajaran sebaiknya menggunakan bahasa yang sederhana dan mudah difahami anak, bila perlu menggunakan ilustrasi gambar atau video. Selain itu pemilihan sumber belajar pun perlu disesuaikan dengan tahapan perkembangan anak yang masih bersifat konkrit. Selama proses pembelajaran berlangsung, guru sebaiknya senantiasa mendampingi anak. Berbeda dengan pembelajar remaja atau orang dewasa yang diasumsikan lebih mandiri dalam mengikuti metode pembelajaran ini.

\section{Metodologi}


Metode penelitian yang digunakan adalah Mixed Method dengan menggunakan dua pendekatan yaitu kualitatif maupun kuantitatif (Creswell, 2009). Pendekatan kualitatif digunakan untuk mengidentifikasi kemampuan bahasa anak. Metode deskriptif dengan pendekatan kualitatif digunakan dalam penelitian ini untuk identifikasi tersebut. Adapun pendekatan kuantitatif dilakukan untuk menganalisis nilai capaian perkembangan bahasa anak.

Subjek penelitian adalah anak-anak TK Alif yang berada di daerah Kecamatan Rancaekek, Kab. Bandung. TK Alif dipilih karena berdasarkan observasi awal, TK ini memiliki keterbatasan sumber belajar, sehingga diharapkan penerapan model Learning based resources ini dapat meningkatkan kualitas pembelajaran. Jumlah sampel yang digunakan adalah 10 orang yang ditentukan secara random. Semua anggota kelompok sampel memiliki karakteristik yang mirip, dilihat dari segi usia, serta kemampuan awal bahasa.

Adapun instrumen penelitian yang digunakan meliputi: lembar observasi, catatan lapangan, rencana kegiatan pembelajaran, lembar pretest dan post test, lembar panduan wawancara, lembar penilaian proses, rekaman video dan kamera foto. Instrumen penilaian capaian perkembangan bahasa anak disusun berdasarkan 15 butir indikator perkembangan bahasa dalam Kurikulum PAUD Permen No.59 Tahun 2003. Berikut adalah butir-butir indikator kemampuan bahasa usia TK (5 s.d 6 tahun).

Tabel 1. Indikator Kemampuan Bahasa Anak

\begin{tabular}{|c|c|}
\hline No & Kemampuan Bahasa Anak \\
\hline 1. & $\begin{array}{l}\text { Menyimak perkataan orang lain (bahasa ibu atau bahasa } \\
\text { lainnya). }\end{array}$ \\
\hline 2. & Mengerti dua perintah yang diberikan bersamaan. \\
\hline 3. & Memahami cerita yang dibacakan \\
\hline 4. & $\begin{array}{l}\text { Mengenal perbendaharaan kata mengenai kata sifat } \\
\text { (nakal, pelit, baik hati, berani, baik, jelek, dsb.) }\end{array}$ \\
\hline 5. & Mengulang kalimat sederhana \\
\hline 6. & Menjawab pertanyaan sederhana \\
\hline 7. & $\begin{array}{l}\text { Mengungkapkan perasaan dengan kata sifat (baik, } \\
\text { senang, nakal, pelit, baik hati, berani, baik, jelek, dsb.). }\end{array}$ \\
\hline 8. & Menyebutkan kata-kata yang dikenal \\
\hline 9. & Mengutarakan pendapat kepada orang lain \\
\hline 10 & $\begin{array}{l}\text { Menyatakan alasan terhadap sesuatu yang diinginkan } \\
\text { atau ketidaksetujuan. }\end{array}$ \\
\hline 11 & $\begin{array}{l}\text { Menceritakan kembali cerita/dongeng yang pernah } \\
\text { didengar. }\end{array}$ \\
\hline 12 & Mengenal simbol-simbol tulisan. \\
\hline 13 & $\begin{array}{l}\text { Mengenal suara-suara hewan/benda yang ada di } \\
\text { sekitarnya. }\end{array}$ \\
\hline 14 & Membuat coretan yang bermakna \\
\hline 15 & Meniru huruf. \\
\hline
\end{tabular}


Data yang didapatkan berupa data kualitatif dan data kuantitatif. Analisis data kualitatif merupakan upaya pencarian pola, persamaan, perbedaan serta hubungan antara data yang terkumpul (Creswell, 2009; McMillan \& Schumacher, 2010). Untuk mengidentifikasi pola yang muncul, data mentah dikelompokkan dengan proses reduksi data, pengkodean, sehingga muncul dalam payung kategori dan tema (McMillan \& Schumacher, 2010). Data kualitatif dianalisis berdasarkan tahap analisis dari Miles dan Huberman (Sugiyono, 2005) yaitu dengan mereduksi data, kemudian penyajian data dan penarikan kesimpulan. Adapun data kuantitatif berupa data nilai capaian perkembangan bahasa anak dianalisis menggunakan rumus mean, variansi dan standar deviasi. Untuk menjaga kevalidan data, diakukan triangulasi data darihasil observas peneliti. Skor penilaian dilakukan dengan skala penilaian 1-4 dengan kriteria penilaian : tidak teramati, tahap awal, berkembang dan konsisten).

\section{Temuan dan Pembahasan}

Masalah yang dianalisis dalam penelitian ini adalah menggambarkan capaian perkembangan kemampuan bahasa anak, khususnya anak-anak TK Alif Kab. Bandung yang merupakan subjek penelitian. Penilaian perkembangan bahasa anak tersebut dilakukan oleh guru kelas yang sehari-hari mengamati perkembangan anak, sehingga diasumsikan lebih mengetahui perkembangan anak. Berikut ini merupakan bagan yang memperlihatkan 15 butir capaian perkembangan anak untuk setiap indikator.

\section{Grafik 1. Capaian Perkembangan Bahasa Anak untuk Setiap Indikator}

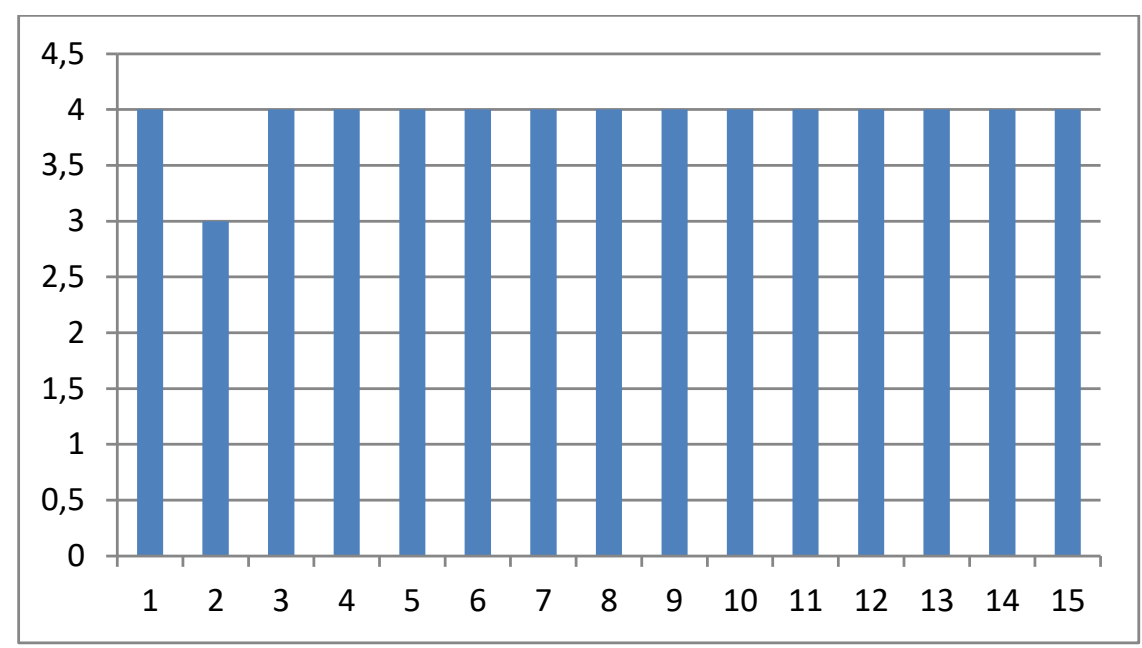

Jika dilihat dari grafik di atas, dapat disimpulkan bahwa hampir keseluruhan indikator dicapai dengan nilai 4 (konsisten). Hanya indikator nomor 2 yaitu mengerti dua perintah yang diberikan secara bersamaan yang masih mendapat nilai 3 (mulai berkembang). Adapun nilai rata-rata untuk seluruh anak adalah 3,65 atau jika dibulatkan menjadi 4 yang bermakna konsisten. 
Temuan ini seiring dengan Logan (1972) yang menyatakan bahwa pada usia 5 tahun anak sudah mulai masuk pada tahap kreatif. Mereka sudah mampu memproduksi bahasa dan berkreatifitas di dalamnya. Jika disimpulkan bahwa siswa-siswi TK Alif rata-rata perkembangan bahasanya baik dan sudah konsisten. Temuan ini memang dapat diprediksi sebelumnya karena analisis atau observasi dilakukan pada akhir tahun ajaran sehingga anak-anak telah matang dan mendapatkan stimulasi yang banyak sekaitan dengan pengembangan bahasanya. Selain itu, pembelajaran bahasa yang dilakukan guru selama observasi dilakukan cukup baik sesuai dengan prinsip pembelajaran yang dikemukakan Musfirah (2009).

Berdasarkan analisis statistika di atas, terbukti bahwa model pembelajaran Learning based resouces efektif dalam mengembangkan kemampuan bahasa anak usia dini dibandingkan metode bermain. Pada pelaksanaan pembelajaran, dilakukan dalam 3 treatmen dengan tema pembelajaran dan target kemampuan bahasa serta sumber belajar yang berbeda-beda. Jumlah anak yang mengikuti pembelajaran sebanyak 7 anak. Tapi 2 anak diantaranya memiliki data penilaian yang tidak lengkap dikarenakan sakit. Karena itu, data yang diolah hanya 5 orang anak. Peningkatan untuk setiap target kemampuan bahasa berdasaran pemanfaatan sumber belajar, disajikan berikut ini.

a. Media Audio Visual

Pemanfaatan media audio visual sebagai sumber belajar dipilih dalam pengembangan bahasa anak dengan indikator; mengenal suara-suara hewan/benda yang ada di sekitarnya. Suara hewan yang dipilih adalah; harimau, ular, srigala, komodo dan singa. Dengan skala penilaian 1-3, perolehan nilai anak adalah tergambar dalam tabel 4.5 di bawah ini:

\section{Tabel 2. Perolehan Skor Anak dengan Sumber Belajar Media Audio Visual}

\begin{tabular}{|r|l|c|}
\hline \multirow{2}{*}{ No } & \multirow{2}{*}{ Inisial Anak } & Skor Anak \\
\cline { 3 - 3 } & & Audio visual \\
\hline 1 & Ahm & 3 \\
\hline 2 & Bgs & 3 \\
\hline 3 & Fyz & 3 \\
\hline 4 & Syf & 3 \\
\hline 5 & Zhl & 3 \\
\hline \multicolumn{2}{|c|}{ Rata-rata } & $\mathbf{3}$ \\
\hline
\end{tabular}

Dari tabel diatas dapat dilihat bahwa seluruh anak memperoleh skor tertinggi, yaitu 3 sehingga skor rata-rata yang diperoleh pun sebesar 3. Seluruh anak mampu mengenali dan membedakan suara harimau, ular, srigala, komodo dan singa. Dapat diasumsikan bahwa pemanfaatan media audio visual dalam pembelajaran bahasa khususnya kemampuan menyimak sangat efektif.

b. Sumber Belajar Manusia 
Sumber belajar kedua yang digunakan dalam mengembangkan kemampuan bahasa anak adalah manusia, dalam hal ini dokter gigi. Tema pembelajaran yang dipilih adalah 'menjaga kesehatan gigi' dan indicator kemampuan bahasa yang dikembangkan adalah 'menyimak perkataan orang lain'. Anak-anak diminta untuk memahami langkah-langkah menggosok gigi yang baik.

Dengan skala penilaian 1-3, perolehan skor anak untuk kemampuan bahasa yang dikembagkan dengan sumber belajar manusia adalah sebagai berikut.

Tabel 3. Perolehan Skor Anak dengan Sumber Belajar Manusia (Dokter Gigi)

\begin{tabular}{|c|l|c|}
\hline \multirow{2}{*}{ No } & \multirow{2}{*}{ Inisial Anak } & Skor Anak \\
\cline { 3 - 3 } & & Dokter \\
\hline 1 & Ahm & 2 \\
\hline 2 & Bgs & 1 \\
\hline 3 & Fyz & 2 \\
\hline 4 & Syf & 3 \\
\hline 5 & Zhl & 1 \\
\hline \multicolumn{2}{|c|}{ Rata-rata } & $\mathbf{1 . 8}$ \\
\hline
\end{tabular}

Berdasarkan table di atas, perolehan nilai anak bervariasi dari 1 s.d 3. Nilai rata-rata yang diperoleh cukup kecil yaitu 1,8. Nilai ini merupakan nilai terkecil dibandingkan dua sumber belajar yang lain. Hal ini terjadi dengan asumsi bahwa anak mengenal dokter gigi sebagai orang asing. Meskipun dokter gigi merupakan profesi yang ahli dalam menjelaskan cara merawat gigi yang baik dan benar, tapi bagi anak, dokter gigi tetaplah orang asing yang belum dekat bagi mereka. Anak perlu waktu untuk beradaptasi dan mempercayai informasi yang disampaikan oleh orang yang baru mereka kenal.

\section{c. Sumber Belajar Buku (Big Book)}

Sumber belajar ketiga yang digunakan adalah buku. Supaya lebih menarik anak, peneliti memilih big book (buku berukuran besar). Tema pembelajaran yang diambil adalah 'Benda di Langit'. Indikator kemampuan bahasa yang dikembangkan adalah 'menceritakan kembali cerita/dongeng yang pernah didengar'. Dengan skala penilaian 1-3, perolehan nilai untuk setiap anak adalah sebagai berikut.

Tabel 4. Perolehan Skor Anak dengan Sumber Belajar Manusia (Dokter Gigi)

\begin{tabular}{|c|l|c|}
\hline \multirow{2}{*}{ No } & \multirow{2}{*}{ Inisial Anak } & Skor Anak \\
\cline { 3 - 3 } & & Buku \\
\hline 1 & Ahm & 3 \\
\hline 2 & Bgs & 1 \\
\hline 3 & Fyz & 1 \\
\hline 4 & Syf & 2 \\
\hline 5 & Zhl & 3 \\
\hline \multicolumn{2}{|c|}{ Rata-rata } & $\mathbf{2}$ \\
\hline
\end{tabular}


Dari tabel di atas, dapat dilihat bahwa nilai rata-rata anak adalah 2 dengan kriteria penilaian baik. Meski skor tertinggi hanya diperoleh dua orang anak, tapi secara keseluruhan, anak-anak mampu menceritakan kembali cerita yang disampaikan melalui media buku.

Dilihat dari analisis capaian kemampuan bahasa anak dalam mengikuti pembelajaran dengan metode learning based resources dengan menggunakan tiga sumber belajar yang berbeda, sumber belajar media audio visual mendapatkan nilai rata-rata yang paling tinggi diantara sumber belajar yang lain. Hal ini diasumsikan bahwa media audio visual dianggap lebih efektif dibandingkan dua sumber belajar yang lain dan menstimulasi anak lebih optimal karena anak menangkap informasi secara audio dan visual. Berbeda dengan sumber belajar buku yang hanya menstimulasi anak secara visual.

Adapun capaian kemampuan bahasa anak dengan sumber belajar manusia mendapat nilai rata-rata yang paling kecil dibandingkan sumber belajar yang lain. Dalam penelitian ini sumber belajar manusia yaitu dokter gigi. Meski dokter gigi menjelaskan dengan sangat jelas mengenai cara menggosok gigi yang baik bahkan dengan menggunakan ilustrasi media gambar, anak masih sulit memahami informasi yang disampaikan dokter gigi tersebut. Hal ini terjadi diasumsikan karena anak baru mengenal dokter gigi tersebut. Anak memerlukan waktu untuk beradaptasi serta memberi kepercayaan kepada dokter gigi yang baru dikenalnya, meskipun dokter gigi adalah seorang profesional di bidang perawatan gigi tapi hal tersebut tidak begitu difahami anak. Di lain kesempatan, peneliti mencoba meminta guru yang menjelaskan cara menggosok gigi yang baik dan benar pada anak. Ternyata anak lebih menerima informasi yang dijelaskan gurunya dari pada oleh dokter gigi. Hal ini diasumsikan karena anak sudah kenal dan dekat serta memberi kepercayaan terhadap gurunya. Anak lebih nyaman belajar dengan orang dekat yang sudah dikenalnya.

\section{PENUTUP}

Dari berbagai temuan dan analisis data dapat disimpulkan bahwa perkembangan bahasa anak secara rata-rata berkembang konsisten diindikasikan dengan perolehan skor nilai kemampuan bahasa sebesar 3,65. Sumber belajar audio visual diasumsikan lebih efektif dari pada sumber belajar manusia dan buku dilihat dari perolehan nilai rata-ratanya. Dalam pemilihan sumber belajar manusia, perlu dipertimbangkan kedekatan sumber dengan anak. Jika perlu, sumber belajar tersebut adalah orang yang dekat dengan anak atau pernah berinteraksi dengan anak sebelumnya.

Disarankan pada guru untuk memanfaatkan bebagai sumber belajar yang ada di sekitar anak. Tetapi dalam pelaksanaannya guru perlu mendampingi anak karena bagi anak usia dini guru merupakan model utama pembelajaran selain orang tua. 


\section{DAFTAR PUSTAKA}

Bowen, C. (1998). Developmental phonological disorders. A practical guide for families and teachers. Melbourne: ACER Press.

Creswell, J. W. (2009). Qualitative, quantitative, and mixed method approaches (third ed.). Thousand Oaks: Sage Publications, Inc.

Logan, Lilian M dkk (1972) Creative Communication, Teaching the Language Art, Toronto: McGraw.

McMillan, J. H., \& Schumacher, S. (2001). Research in education: A conceptual introduction (5th ed.). New York: Longman.

Musfirah, Tadkiroatun (2008) Menumbuhkembangkan Baca Tulis Anak Usia Dini. Jakarta: Grasindo

Nasution. S (2006). Berbagai Pendekatan Dalam Proses Belajar Mengajar. Jakarta : Rineka Cipta.

Peterson, Candida (1996) Looking forward through the Lifespan. Sydney: Prentice Hall.

Sugiyono (2005) Metode Penelitian Pendidikan. Bandung: Alfabeta

Suryosubroto, B, Proses Belajar Mengajar di sekolah, Jakarta: PT. Rineka Cipta, 1997, cet. 1

Suyanto, Slamet (2005) Dasar - Dasar Pendidikan Anak Usia Dini, Yogyakarta: Hikayat Publishing.

Yawkey, Thomas D dkk (1981) Language Arts and the Young Child. Illinois: Peacock Publisher 